\title{
Haemorrhages of the Sole Horn of Dairy Cows as a Retrospective Indicator of Laminitis: An Epidemiological Study
}

\author{
By C. Bergsten
}

The Experımental Station, Veterinary Instıtute, Swedish University of Agriculture Sciences, Skara, Sweden.

\begin{abstract}
Bergsten, C.: Haemorrhages of the sole horn of dairy cows as a retrospective indicator of laminitis. An epidemiological study. Acta vet. scand. 1994, 35, 55-66. - Eleven herds with clinical laminitis problems and 11 control herds were studied for 2 consecutive years. All the claws were trimmed and photographically recorded once each year, 2 to 6 months after the cows had calved. The haemorrhages of the sole horn were evaluated and scored for each digit, and data relevant to the factors associated with an increased risk of laminitis for each herd were collected and related to these scores for sole haemorrhages. It was found that the laminitic herds were more prone to the sole lesions than the control herds, the hind claws were more prone than the front claws, the primiparous cows were more prone than the multiparous cows and the Swedish Friesian cows were more prone than the Swedish Red and White cows. High scores were also correlated with hard floors (ie concrete) in the cow stalls, with fewer than 4 daily feedings of concentrates, with a short time allocated for the cows to eat concentrates, with feeding concentrates only at the first meal in the morning and in the afternoon and with the interaction between these last 2 variables.
\end{abstract}

claw diseases; feeding routines; management; environmental factors.

\section{Introduction}

Laminitis (Pododermatitis aseptica diffusa) is an important metabolic disease of cattle ( $B a$ zeley \& Pinsent 1984) and is defined as a diffuse aseptic inflammation of the corium. It occurs in acute, subacute and chronic forms and with different degrees of severity, and has been thoroughly described by several authors (e.g. Nilsson 1963, Maclean 1965, Edwards 1982, Greenough 1982, Toussaint Raven 1985). Severe cases of laminitis are easy to diagnose clinically because of the signs of pain from the claws, which cause the cow to stand stiffly in an abnormal position. Milder clinical cases are more difficult to diagnose. Moreover subclinical laminitis is very common. The disease is often considered to be a herd problem associated with environmental, managemental and nutritional risk factors (Greenough 1985, David 1989). In studies of the aetiology, pathogenesis and epidemiology of the disease, pathognomonic markers would be of great value. Peterse (1980) proposed that discolourations due to the residues of haemorrhages in the sole of the claw might serve as such markers, because laminitis is characterised by hyperaemia and capillary lesions with oedema and haemorrhages in the corium of the claw (Nilsson 1963, Maclean 1971a, Andersson \& Bergman 1980). These lesions might be expected to interfere with the nutrition of the horn producing cells,leading to the 
degeneration of the keratocytes and the derangement of horn production. The haemorrhages can be found in the growing horn, and since the claw horn generally grows at approximately $5 \mathrm{~mm}$ a month (Greenough et al. 1981) and the thickness of the sole after claw trimming should be about $10 \mathrm{~mm}$, it should normally take approximately 2 months before a haemorrhage in the corium becomes visible in the sole surface when the claw is trimmed. If the lesions in the corium do not heal during this period, no normal horn will be produced, and a deep defect, called a sole ulcer (Pododermatitis circumscripta), will develop (Smedegaard 1964, Peterse 1980).

By using a standardized photographic technique the distribution and severity of any haemorrhages in the sole surface can be recorded (Bergsten et al. 1986, Bergsten 1993). This technique should make it possible to investigate the importance of the aetiological factors involved in clinical and subclinical laminitis in a reasonably objective way.

Most cases of laminitis are diagnosed shortly after a cow has calved (Andersson 1980) and it can therefore be assumed that peripartal factors are of great importance in the aetiology of the disease. Among such factors are changes of environment, changes in feeding and management, stress and changes in the patterns of secretion of hormones (David 1989). In the present investigation the photographic technique was used in a field study with the aims of investigating the relationships between haemorrhages of the sole retrospectively found at claw trimming and laminitis, and of evaluating the relative importance of the herd-related, peripartal risk factors for haemorrhages of the sole.

\section{Material and methods}

The investigation made use of dairy herds in 1 veterinary service district in south-west Swe- den through 2 successive years, the first from September 1985 to August 1986 and the second from September 1986 to August 1987. Eleven susceptible herds were chosen by the practising veterinarians because several cases of clinical laminitis had occurred in them during the year before the first experimental year; these are referred to as the laminitic herds. Eleven control herds were chosen because they had had no reported clinical cases of laminitis treated by the veterinarians during the same year. The control herds were as similar as possible to the laminitic herds in terms of their location, size, predominant calving season and milk production level. During the winter housing period all the cows were tied in stalls; 9 of the laminitic herds and 10 of the control herds had longstalls.

All the herds took part in the official Milk Control System. The average number of cows in the laminitic herds was 25.7 (range 15-33) and in the control herds 24.9 (range 17-32). Five laminitic herds and 7 control herds had only Swedish Red and White cattle and 1 laminitic herd had only Swedish Friesian cattle. All the other herds had both breeds or crosses between them. Of the cows in the laminitic herds $62.3 \%$ were pure Red and White and $27.4 \%$ were pure Friesians; in the control herds $88.5 \%$ were pure Red and White and $8.5 \%$ were pure Friesians.

The mean annual milk yield of the laminitic herds in the year before the first experimental year was $7204 \mathrm{~kg} \mathrm{4 \%}$ fat-corrected milk (FCM; range 6741-7852) and the mean yield of the control herds was $6899 \mathrm{~kg}$ FCM (range 5177-7691) The cows in the laminitic herds were on average slightly younger than those in the control herds; the mean \pm sd numbers of lactations were $2.14 \pm 1.28$ and $2.35 \pm 1.54$ respectively.

The majority of the calvings occurred between August and December; during the first 
year $64 \%$ of the cows in the laminitic herds and $72 \%$ of the cows in the control herds calved during this period, and during the second year the corresponding estimates were $72 \%$ and $70 \%$ respectively. The calving dates of the primiparous cows were on average 6 and 10 days earlier than the calving dates of the multiparous cows during the first and second year, respectively.

In both years only the cows which calved between August 1, and December 31 were included in the trial. They were clinically examined, and had their claws trimmed and photographed during a 4 week period in February and March.

During the first year 352 cows were recorded and during the second year 351 cows were recorded (Table 1). During the first year the mean number of cows recorded in the individual herds was 15.6 (range 8-26) in the laminitic herds and 16.2 (range 6-31) in the control herds; the corresponding figures during the second year were 16.1 (range 5-27) and 16.0 (range 12-30). Ninety-one of the cows in the laminitic herds and 97 of the cows in the control herds were recorded in both years.

The claws of the cows in each herd were trimmed and recorded only once each year. As a result the cows had calved at least 7 weeks and not more than 24 weeks before their claws were photographed. The claws were trimmed to normal size and were then photographed in a standardized way (Bergsten 1993). The slides were evaluated in a double-blind test by 2 observers after the end of the trial. The severity and the distribution of the haemorrhages in each digit were scored on a scale from 0 to 5; 0 indicated no haemorrhages and 5 indicated severe haemorrhages covering a large area of the claw or a sole ulcer (for details see Bergsten 1993). For each cow a total score for all 8 digits was calculated (maximum points 40 ) and scores were also calculated separately for the front legs (maximum points 20 ) and for the hind legs (maximum points 20 ).

Data about the milk yields of the herds and the incidence of diseases during the 2 experimental years were obtained from the monthly milk recordings and from the summaries of the annual herd records used in the official Milk Control System.

During the second year additional information was recorded concerning the type of tiedup systems, the type of stall surface, bedding, the hygiene of the stall, the cleanliness of the animals, the cleanliness of their claws, the grouping of cows in the stable, whether supplementary feeding was provided during the summer, the routines used when the cows were brought indoors for the winter season, the amounts of different feedstuffs fed at different stages of lactation, the type of roughage, the type of grain, the type of commercial protein feed, the relative proportions of roughages and concentrates, the number of times per day when the cows were fed concentrates, the total time available for eating, the order in which roughages and concentrates were fed, and the energy and protein balances during the period 1 month before to 1 month after calving.

\section{Statistical analysis}

The Wilcoxon 2 sample test was used to compare the points scored in the different claws of cows in the laminitic and control herds, and in different breeds and different ages of cows (primiparous, multiparous and all cows). Chisquared tests were used for comparisons between the cows with no signs of haemorrhages of the sole (total score $=0$ ) and the cows which scored a total of 7 or more points.

The relationships between the haemorrhages of the sole and certain herd variables were studied by using the General Linear Models 
procedure in SAS (SAS Institute Inc. 1987). A stepwise regression model was used to estimate the levels of significance of a large number of variables. In the final model the following variables were retained: age expressed as the average herd lactation number divided into 3 classes: $<2.2=$ class $1 ; 2.2-2.5=$ class 2 ; $>2.5=$ class 3 ); the type of feedstuff fed at the first daily meal (only concentrates = class 1 ; concentrates + roughage $=$ class 2 ; only roughage $=$ class 3 ), the number of times concentrates were fed during $24 \mathrm{~h}$ (twice $=$ class $1 ; 3$ times = class $2 ; \geq 4$ times = class 3$)$, the total time available for eating $(4-6 \mathrm{~h}=$ class $1 ; 6-8 \mathrm{~h}$ $=$ class $2 ;>8 \mathrm{~h}=$ class 3 ), the intakes of energy and protein as a percentage of the cows' requirements, stall surface (concrete = class 1 ; concrete and rubber mats $=$ class 2 ; rubber mats = class 3 ), and the interaction between the type of feedstuff fed at the first daily meal and the total time available for eating.

\section{Results}

Between August and December of the first year of the study 28 cows in the laminitic herds were treated by veterinarians for clinical laminitis compared with 5 in the control herds. The corresponding figures for the same period of the second year were 7 in the laminitic herds and 6 in the control herds. Of all the 46 cows treated, $14(29 \%)$ were sent to slaughter before the condition of their clows was recorded.

During both years the total number of points scored by all the digits of all cows was significantly higher in the laminitic herds than in the control herds (Table 1). The differences mostly remained significant when only the multiparous cows were considered (Table 2) but were mostly not significant for the primiparous cows (Table 3 ). In both years the primiparous cows had higher scores than the multiparous cows in both the laminitic and control herds. However, the difference was not significant for the laminitic herds during the first year.

In both years the points scored for haemorrhages by the front digits of both primiparous and multiparous cows were slightly higher in the laminitic herds than in the control herds. However, the differences were not significant for the multiparous cows in the second year or for the primiparous cows in the first year. In comparisons between different age groups (Tables 2 and 3) the primiparous cows had slightly higher scores in both types of herds in both years, but the difference was only significant $(\mathrm{p}<0.05)$ in the laminitic herds during the second year.

The points scored for haemorrhages by the hind digits were on average about twice the points scored by the front digits (Tables 1,2 and 3), and the differences between the laminitic and control herds and between age classes were virtually the same for the hind digits as for all the digits.

The scores for haemorrhages (all cows, both years) were significantly $(\mathrm{p}<0.001)$ higher for the inner digits $(\overline{\mathrm{x}}: 0.84)$ than for the outer digits $(\overline{\mathrm{x}}=0.34)$ of the front claws, and significantly $(\mathrm{p}<0.001)$ higher for the outer digits $(\bar{x}=1.91)$ than for the inner digits $(\bar{x}=0.63)$ of the hind claws.

In comparisons between breeds the Friesian cows had higher scores than the Red and White cows for all the digits, for the front digits and for the hind digits in both the laminitic and control herds in both years. The differences were significant $(\mathrm{p}<0.01$ for the first year, $p<0.001$ for the second year) only for the multiparous cows in the laminitic herds.

The percentage of cows with no signs of haemorrhages of the sole in the laminitic herds was about half that in the control herds during the first year. Moreover, the percentage of cows with a total score of 7 or more during this 


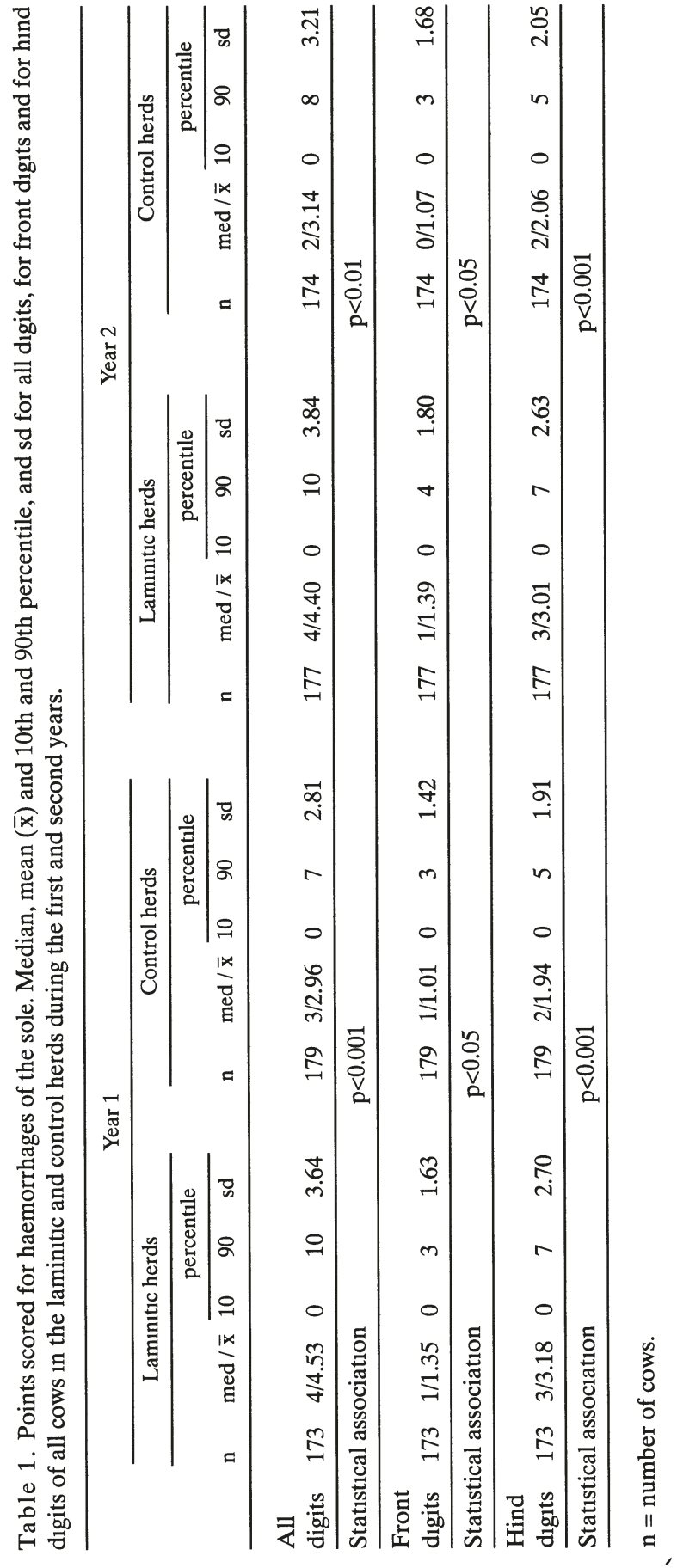


列

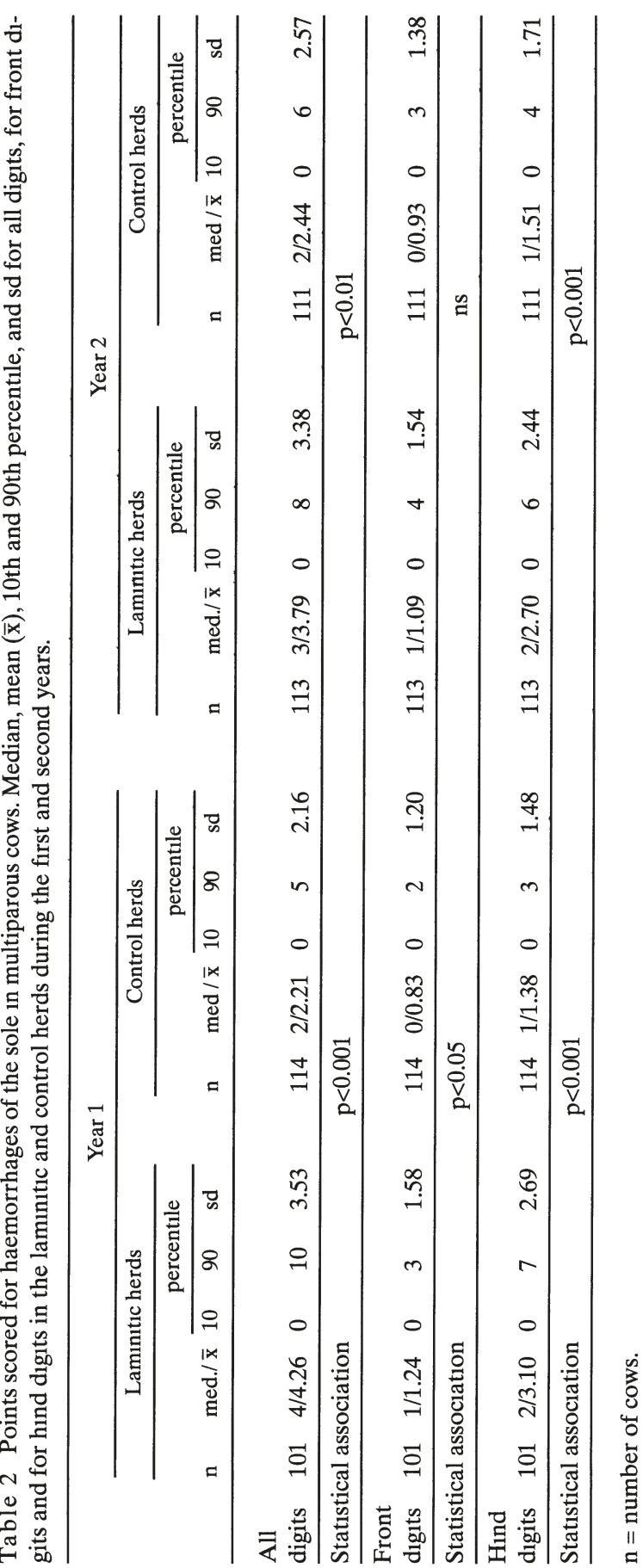




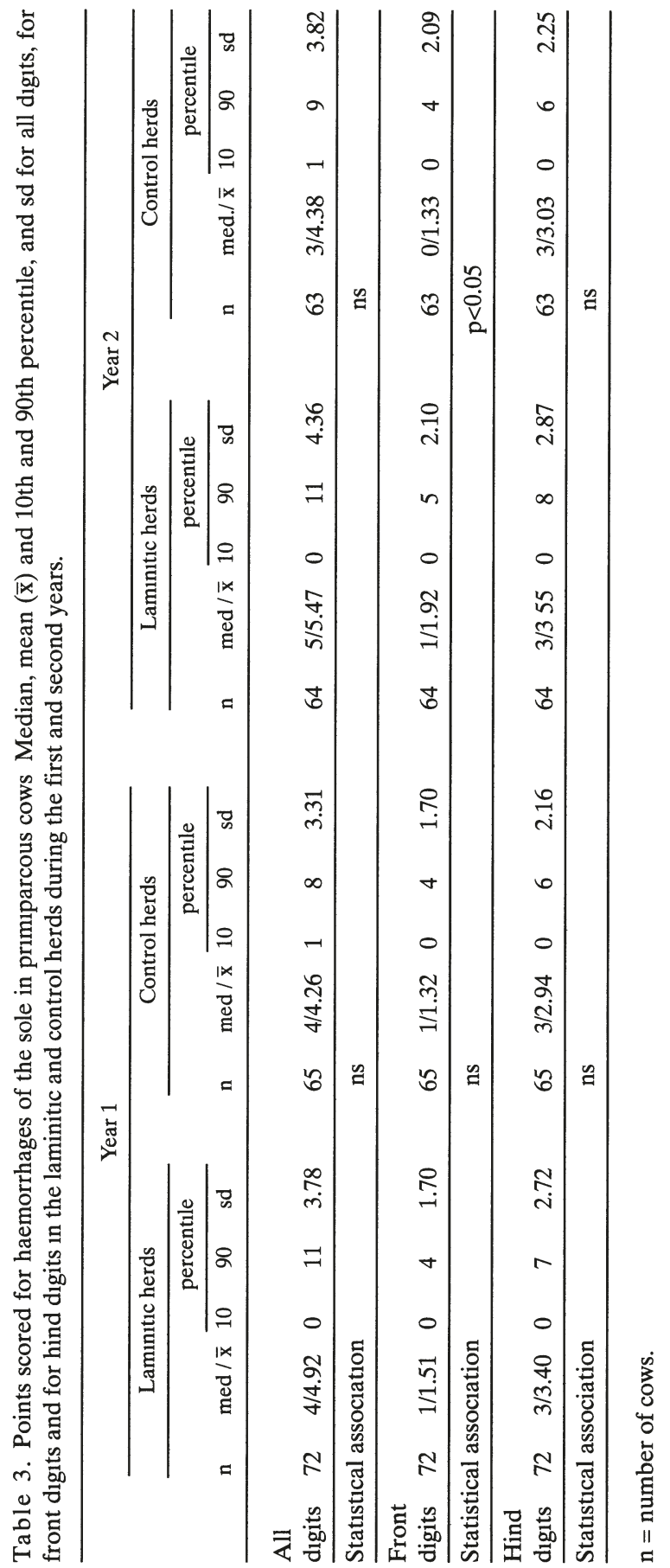


Table 4. Numbers and percentages of cows with total points of 0 and $\geq 7$ in the laminitic and control herds during the first and second years.

\begin{tabular}{|c|c|c|c|c|c|c|c|c|}
\hline & \multicolumn{4}{|c|}{ Year 1} & \multicolumn{4}{|c|}{ Year 2} \\
\hline & \multicolumn{2}{|c|}{ Scorıng $=0$} & \multicolumn{2}{|c|}{ Scoring $\geq 7$} & \multicolumn{2}{|c|}{ Scoring $=0$} & \multicolumn{2}{|c|}{ Scoring $\geq 7$} \\
\hline & Number & $\%$ & Number & $\%$ & Number & $\%$ & Number & $\%$ \\
\hline Lamınitic herds & 21 & 12 & 45 & 26 & 28 & 17 & 42 & 24 \\
\hline Control herds & 38 & 21 & 19 & 11 & 31 & 18 & 26 & 15 \\
\hline Statistical association & \multicolumn{2}{|c|}{$p<0.001$} & \multicolumn{2}{|c|}{$p<0.001$} & \multicolumn{2}{|c|}{ ns } & \multicolumn{2}{|c|}{ ns } \\
\hline
\end{tabular}

year was more than twice as high in the laminitic herds as in the control herds (Table 4). No significant differences were found during the second year.

\section{Epidemiology}

The total scores for haemorrhages of all the digits were significantly $(\mathrm{p}<0.05)$ negatively correlated with the age of the cows and with the number of times per day when concentrates were fed.Increased scores were also associated with a short time available for eating, and with the habit of offering only concentrates at the first meal in the morning and in the afternoon, and with an interaction between these 2 factors. There was also a significant correlation between high scores for haemorrhages and stalls with a hard surface. All other environmental, management, feedstuffs, feeding, and production variables were eliminated in the statistical models used.

\section{Discussion}

Owing to the variable and diffuse signs of clinical laminitis and to the fact that cases of subclinical laminitis are very common (Peterse 1980, Greenough 1985) studies of laminitis based solely on clinical signs, particularly from animals in the field, are of limited value. Peterse (1980) and Thysen et al. (1981) recorded changes in the surface of the sole which they considered would provide retrospective information about the pathological processes occurring in the corium of cows with subclinical laminitis. The results of the present investigation indicate that there was also a positive correlation between the occurrence of haemorrhages in the sole and the incidence of clinical laminitis, in agreement with the results of Livesey \& Fleming (1984). Taken together, these results strengthen the evidence for the hypothesis that recording haemorrhages in the sole of the claw can be used to study the aetiology and pathogenesis of both clinical and subclinical laminitis.

The photometric method (Bergsten 1993) was used in order to avoid as far as possible any subjectivity in the evaluation of the haemorrhages. In an ideal study of the relative importance of the aetiological factors involved in the development of laminitis, many of which are related to the time of calving, it would have been best to photograph all the cows at some fixed time between 75 and 100 days after calving (Peterse 1980, Bergsten et al. 1986). However, such a scheme could be not practiced in the present trial, and at the time of recording the cows varied considerably in relation to calving. In spite of this variation, and even if there is a chance that some of the haemorrhages might have disappeared in some cases when the trimming was not made until 20-24 weeks after calving, the recording schedule used should have yielded valuable information about the calving-related risk factors for laminitis. The analytical errors should 
have been equal for both the laminitic and the control herds because they were both clawtrimmed during the same week and the distribution of the calvings was similar in both types of herds. The average intervals between calving and claw-trimming were 134 days for the laminitic herds and 140 days for the control herds. Furthermore, all the claw-trimming was done gradually, and if any superficial haemorrhages were found they were photographically recorded before the trimming was completed. As a result the final record for each cow included all the defects observed.

Eleven of the 33 cows treated for clinical laminitis during the first year were culled within a few months after the treatment, and during the second year 3 of the 13 treated cows were culled in the same way. Taken together with the fact that the cows in the laminitic herds were on average slightly younger than those in the control herds, these figures indicate that treatment for laminitis is often unsuccessful and that cows with clinical laminitis have a poor prognosis and an expected shorter productive life. These results agree with the conclusions of Weaver $(1971,1979)$ and Maclean (1971b). Furthermore, the fact that a majority of the cows that had been culled for clinical laminitis before the claw-trimmings in February and March were from the laminitic herds implies that the differences recorded between the 2 types of herds would have been to some extent underestimated. It is also plausible that the farmers in the laminitic herds had got an increased consciousness of the importance of the claw problems and therefore had carried out preventive measures. The yearly claw trimming included in the study might also be considered as a preventive measure in both types of herds.

During the first year only $12 \%$ of the cows in the laminitic herds and $21 \%$ of the cows in the control herds had no signs of haemorrhages of the sole. During the second year the figures were $17 \%$ for the laminitic herds and $18 \%$ for the control herds (Table 4). Thus in both years there was a very high prevalence of haemorrhages of the sole. High prevalences of pathological claw lesions have previously been reported both from Sweden (Anderson \& Lundström 1981, Strandberg et al. 1992) and other European countries (Peterse 1980, Bradley et al. 1989, Philipot et al. 1990). Even if the latter investigations recorded other claw diseases as well, there can be little doubt that subclinical laminitis is a very common disease, at least in countries in which there is intensive dairy production.

The scores for the hind digits were higher than for the front digits, a result corresponding to the results of earlier investigations (Smedegaard 1964, Andersson \& Lundstrom 1981, Thysen et al. 1981, Edwards 1982, Russell et al. 1982). This result is in one sense surprising, because the clinical signs of laminitis are usually more obvious when the disease affects the front claws. Nilsson (1963) found that cows with acute laminitis showed more severe clinical signs when the disease affected the front claws, whereas cows with chronic laminitis showed more severe signs when the disease affected the hind claws. The higher scores for the hind digits could have been explained by a higher load on the hind claws during late pregnancy, but the load distribution between the fore and hind claws is in fact not changed in the peripartal period (Scott 1988). In the present study the haemorrhages in the front claws were more common in the inner than in the outer digits, whereas the reverse was the case for the hind claws. This verifies earlier findings of Smedegaard (1964), Andersson \& Lundström (1981), Thysen et al. (1981). In the early stages, when nothing abnormal can be seen in the sole horn, Smedegaard (1964) re- 
ported that affected hind limbs are usually placed in an abducted position, but affected forelimbs are usually adducted. The explanation is probably that a cow with sore inner digits of the front claws can reduce the load on them by crossing her legs, however, it is more difficult for a cow to reduce the load on the sore outer digits of its hind claws. The strain on the hind outer digits is therefore likely to be greater, with the likelihood of a greater incidence of chronic laminitis, haemorrhages of the sole and sole ulcers in these digits. However, other factors probably contribute to the higher scores observed in the hind digits, for example their functional anatomy (Smedegaard 1964, Toussaint Raven 1985) and the fact that they are more exposed to urine and faeces (Nilsson 1963, David 1989, Greenough \& Vermunt 1991).

In both the laminitic and the control herds the primiparous cows had higher scores for haemorrhages of the sole than the multiparous cows. This result is in agreement with the results published by Greenough \& Vermunt (1991), who recorded the highest cumulative scores for haemorrhages of the sole in firstcalving heifers close to calving and/or 2 months after calving, and with reports that laminitis is most common in primiparous cows (Peterse 1980, Thysen et al. 1981, Bazeley \& Pinsent 1984). However, Nilsson (1963) reported that this was the case only for acute laminitis and that chronic laminitis was more common in older cows, and Andersson \& Lundström (1981) also reported that the prevalence of chronic laminitis and the prevalence of haemorrhages of the sole increased with increasing age. However, these divergent results may have been due to the fact that the information was derived from slaughterhouse material, in which older cows with chronic laminitis may have been overrepresented.

The higher points scored by the Swedish Frie- sian cows than by the Swedish Red and White cows can be related to the higher culling rate among Friesians for diseases of the legs and claws (6.4\% compared with 5.1\%; SHS 1991). Several other authors have also reported more claw lesions in Friesians and Holsteins than in other breeds (Nilsson 1963, Smedegaard 1964, Peterse 1980, Andersson \& Lundstrom 1981). In the present investigation the distribution of the breeds was not perfectly uniform between the 2 types of herds, but the similarity of the patterns of disease within the breeds in each type of herd must have significantly reduced any possible breed effect.

High scores for haemorrhages in the sole were significantly related to a hard floor surface of the cow stalls. In 1 of the laminitic herds there was a large decrease ( 2.9 points) between the first and second years in the total points scored for all digits. In this herd rubber mats had (on the initiative of the farmer) been introduced in the intervening period. The importance of the hardness of the stall floor as a factor contributing to the incidence of laminitis has previously been pointed out not only for cows tied in stalls (Nilsson 1963, Fjeldaas 1983) but also for cows in loose-housing systems (Bazeley \& Pinsent 1984, Brochart 1987, Bradley et al. 1989, David 1989).

The nature of the bedding material (straw or sawdust) had no influence on the incidence of haemorrhages of the sole, probably because on most of the farms the layers of bedding were thin or had been moved away from where the cows stood. However, Colam-Ainsworth et al. (1989) found that the incidence of laminitis among primiparous cows was higher when little or no bedding material was used in the cubicle than when large amounts of bedding were used.

The scores for haemorrhages of the sole were increased when concentrates were fed only a 
few times a day, or when short eating times were combined with only concentrates being fed at the first meal in the morning and afternoon. These feeding routines may be presumed to lead to variations in the ruminal environment, and particularly to intermittent decreases in ruminal pH (Kaufmann 1976, Sutton et al. 1986). Weaver (1979) and Greenough \& Vermunt (1991) proposed that feeding regimens which tend to raise ruminal $\mathrm{pH}$ should reduce the incidence of laminitis.

No relationship was found between the intensity of feeding during the peripartal period and the incidence of haemorrhages of the sole. One possible reason may have been that the methods for recording were not sufficiently sensitive. However, such a relationship has often been reported as a result of the practical experience of farmers, and further experimental trials to explore the relationship are in progress.

\section{Acknowledgement}

The investigation was supported by the Agricultural office at the county of administration in Alvsborg.

\section{References}

Andersson L: Frequency studies and clinical observations in bovine laminitis Nord. Vet. Med. 1980, 32, 301-307.

Andersson L, Bergman A P Pathology of bovine laminitıs especially as regards vascular lesions. Acta vet. scand. 1980,21 , 559-566.

Andersson L, Lundstrom $K$. The influence of breed, age, bodyweight and season on digital diseases and hoof size in dairy cows. Zbl.Vet.Med.A 1981, 28, 141-151.

Anonymous: Årsstatıstik inklusive djurhalsovård 1989/90. (Annual data including anımal health). Svensk Husdjursskotsel, Hållsta, Sweden 1991, meddelande $\mathrm{Nr} 167$.

Bazeley K, Pinsent PJN. Prelımınary observatıons on a series of outbreaks of acute lamınitis in dairy cattle Vet. Rec. 1984, 115, 619-622.

Bergsten, C: A photometric method for recording hoof diseases in cattle, with special reference to haemorrhages of the sole. Acta vet. scand. 1993, 34, 281-286.

Bergsten C, Andersson L, Wiktorsson H: Effects of feeding intensity at calving on the prevalence of subclinical laminitis. Proc. Vth Int. Symp. Dis. Rumınant Digit. Dublin, Ireland 1986,33-38.

Bradley HK, Shannon D, Neulson DR: Subclınical laminitis in dairy heifers. Vet. Rec. 1989, 125, 177-179.

Brochart M. Foot lameness of the cow, a multifactorial disease. In: Wierenga HK, Peterse DJ. (eds): Cattle housing systems, lameness and behaviour. Martinus Nijhoff Publishers, Dordrecht/Boston/Lancaster 1987, 159-165.

Colam-Ainsworth P, Lunn GA, Thomas RC, Eddy $R G$. Behaviour of cows in cubicles and its possible relationship with laminitis in replacement dairy heifers. Vet. Rec. 1989, 125, 573-575.

Davıd GP. Epidemiological factors associated with a high incidence of sole ulcer and white line disease in dairy cattle. Proc. Soc. Vet. Epid. Prev. Med., Exeter, England 1989, 149-158.

Edwards $G B$. Acute and subacute lamınitis in cattle. Vet. Annual 1982, 22, 99-106.

Fjeldaas T: Klauv- og ekstremitetslıdelser hos mjølkeku 1 relasjon tıl miljø. (The influence of the stall environment on bovine hoof and limb disease.) Thesis, Oslo, Norway 1983.

Greenough PR: Lamınitis, a review. Proc.IVth Int.Symp. Dis. Ruminant Digit, Paris, France 1982, 6 pp.

Greenough PR: The subclinical laminitis syndrome. Bov Pract. 1985, 20, 144-149

Greenough PR, MacCallum, FJ, Weaver AD. Lameness in cattle. John Wright \& Sons, Bristol, England 1981.

Greenough PR, Vermunt JJ· Evaluation of subclınical laminitis in a dairy herd and observations on associated nutritional and management factors. Vet. Rec. 1991, 128, 11-17.

Kaufmann W: Influence of the composition of the ration and the feeding frequency on $\mathrm{pH}$ regulation in the rumen and on feed intake in ruminants. Livestock Prod. Sci. 1976, 3, 103-114.

Livesey CT, Fleming $F L \cdot$ Nutritional influences on laminitis, sole ulcer and bruised sole in Friesian cows. Vet. Rec. 1984, 114, 510-512.

Maclean CW. Observations on acute laminitis of cattle in South Hampshire Vet Rec. 1965, 77, 662672.

Maclean,CW. The histopathology of laminitis in dairy cows. J.comp Path. 1971a, 81, 563-570. 
Maclean, CW: The long term effects of laminitis in dairy cows. Vet. Rec. 1971b, 89, 34-37.

Nilsson, SA: Clinical, morphological and experimental studies of laminitis in cattle. Acta vet. scand. 1963, 4, Suppl. 1.

Peterse DI: Judgement of bovine claws by the occurrence of sole lesions. Thesis, Utrecht, the Netherlands 1980.

Phillpot J-M, Pluvinage P, Cimarost I, Luquet F: On indicators of laminitss and heelhorn erosion in dairy cattle: a research based on the observation of digital lesions, in the course of an ecopathological survey. Proc. VIth Int. Symp. Dis. Rum1nant Digit. Liverpool, England 1990, 184-198.

Russell AM, Rowlands GJ, Shaw SR, Weaver AD: Survey of lameness in British dairy cattle. Vet. Rec. 1982, 111, 155-160.

SAS Institute Inc: SAS/STAT ${ }^{\mathrm{TM}}$ Guide for Personal Computers. Version 6 Edition Cary, NC, USA, 1987.

Scott $G B \cdot$ Lameness and pregnancy in Friesian dairy cows. Br. vet. J. 1988, 144, 273-281.

Smedegaard $\mathrm{HH} \cdot$ Contusion of the sole in cattle. The Veterinarian 1964, 2, 119-139.

Strandberg P, Gundel M, Larsson B, Johansson $O$ : Hoof health in Swedish dairy cows and breeding values for hoofs and legs. Proc. VIIth Int. Symp. Dis. Ruminant Digit. Rebild, Denmark 1992, p 26, (stencil).

Sutton JD, Hant IC, Brosten WH, Elliot RJ, Schulter $E$ : Feeding frequency for lactating cows, effects on rumen fermentation and blood metabolites and hormones. Brit. J. Nutr. 1986, 56, 181-192.

Thysen I, Buchwald E, Smedegaard HH: Skader og sygdomme in malkekoens klove. (Lesions and diseases in the claw of the dairy cow). Beretning fra Statens husdyrbrugsfors $\varnothing \mathrm{g}$, København, 1981, 515, 49-72.

Toussaint Raven E: Cattle foot care and claw trimming. Farming Press, Ipswich, England 1985.

Weaver $A D \cdot$ Solar penetration in cattle: its complications and economic loss in one herd. Vet. Rec. 1971, 89, 288-296.

Weaver $A D$ : Prevention of laminitis in dary cattle. Bov. Pract. 1979, 14, 70-72.

\section{Sammanfattning \\ Blodningar $\iota$ sulhornet hos mjolkkor som retrospek- tıv indikator på fång: En epıdemıologısk studie.}

Under 2 på varandra foljande år studerades 11 besattnıngar med klinıska fångproblem och 11 kontrollbesattningar. Klovsulornas utseende hos samtliga kor dokumenterades med foto 1 samband med verknıng. Graden av sulblodningar bedomdes for varje klov och angavs som sulblodnıngspoang. Fångbesảttnıngarna hade signifikant hogre sulblodnıngspoang an kontrollbesattningarna, bakklovarna hogre poang an framklovarna, forstakalvarna hogre poang an de aldre korna och SLB-korna hogre poang an SRB-korna.

Rıskfaktorer fơr fång relaterades till sulblodningspoangen. Hogre sulblodningspoang kunde korreleras till hårt båspallsunderlag (betong), till färre àn fyra kraftfodergivor per dag, till kort attıd, till utfodring av enbart kraftfoder som forsta mål vid morgon- och eftermiddagsutfodringen samt till samspelet mellan de 2 sistnamnda parametrarna

(Recelved October 15, 1993; accepted November 19, 1993).

Reprints may be requested from: C. Bergsten, The Experimental Station, Veterınary Institute, P.O. Box 234, Swedish University of Agricultural Sciences, S-532 23 Skara, Sweden. 